Archived version from NCDOCKS Institutional Repository http://libres.uncg.edu/ir/asu/

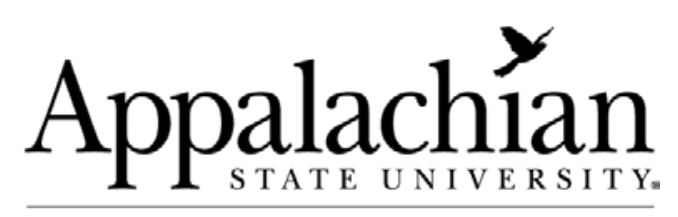

B O O N E, NORTH CAROL I N A

\title{
Do-It-Yourself Projects As Path Toward Female Empowerment In A Gendered Market Place
}

\author{
By: Marco Wolf, Pia A. Albinsson, and Cherylynn Becker
}

\begin{abstract}
The role of women as homeowners and heads of households are changing the dynamics in which women engage in do-it-yourself (DIY) behavior. Because there is limited extant theory associated with female involvement in DIY behavior, a qualitative study using in-depth interviews was conducted. Through grounded theory analysis several themes emerged during the coding process, and the themes of empowerment were especially relevant to the informants in this study. Five dimensions of empowerment were identified: empowerment through project initiation, production mastery, adding economic value to goods and services, unleashing creative potential, and empowerment through ownership. The findings show women's involvement in DIY behavior and the consumption of DIY-related goods is closely tied to the concept of female empowerment.
\end{abstract}

Wolf, M. , Albinsson, P. A. and Becker, C. (2015). Do-It-Yourself Projects as Path toward Female Empowerment in a Gendered Market Place. Psychol. Mark., 32: 133-143. doi:10.1002/mar.20768. Publisher version of record available at: https://onlinelibrary.wiley.com/doi/10.1002/mar.20768 


\title{
Do-It-Yourself Projects as Path toward Female Empowerment in a Gendered Market Place
}

\author{
Marco Wolf \\ University of Southern Mississippi \\ Pia A. Albinsson \\ Appalachian State University \\ Cherylynn Becker \\ University of Southern Mississippi
}

\begin{abstract}
The role of women as homeowners and heads of households are changing the dynamics in which women engage in do-it-yourself (DIY) behavior. Because there is limited extant theory associated with female involvement in DIY behavior, a qualitative study using in-depth interviews was conducted. Through grounded theory analysis several themes emerged during the coding process, and the themes of empowerment were especially relevant to the informants in this study. Five dimensions of empowerment were identified: empowerment through project initiation, production mastery, adding economic value to goods and services, unleashing creative potential, and empowerment through ownership. The findings show women's involvement in DIY behavior and the consumption of DIY-related goods is closely tied to the concept of female empowerment.
\end{abstract}

Historically, the home and the space within have been subject to complex negotiation of ideas about male and female identity. With the end of the Victorian era, and the beginning of the industrial revolution, many changes in society were reflected in the home. The alteration of the restrained and distant Victorian father into the engaged and present suburbandad was one of the more significant changes in the structure of the modern family, and the male use of tools around the house was a critical component of that change. By taking over chores previously done by professionals,

the do-it-yourselfer created a new role for himself inside the house (Gelber, 1997). In theory, this overlapped with a widening female household sphere, but in practice it was sufficiently distinct; so by the end of the $1950 \mathrm{~s}$, the term "do-it-yourself" (DIY) became part of the definition of suburban husbandry (Gelber, 1997).

DIY is defined as "activities in which individuals engage raw and semi-raw materials and component parts to produce, transform, or reconstruct material possessions, including those drawn from the natural environment" (Wolf \& McQuitty, 2013, p. 195). Despite its important economic role of forecasted 2014 sales of $\$ 313$ billion (Home Improvement Research Institute, 2014), DIY received limited attention from consumer behaviorists. Research on DIY consumption dates back to the 1980s but largely focuses on profiling the DIY segment (Bush, Menon, \& Smart, 1987; Hornik \& Feldman, 1982; Schwartzlander \& Bowers, 1989). More recent studies explore DIY consumption in the light of competence, skills, and the creativity utilized to transform raw material resources into possessions (Chen \& Chandler, 2009; Ridgway \& Price, 1994; Watson \& Shove, 2008). Others have begun to examine the underlying motivations of DIY behavior and suggest motivations may differ based on market situations and personal identity (Williams, 2008; Wolf \& McQuitty, 2011, 2013).

The present study was inspired by Wolf and McQuitty's (2011) framework of DIY motivations and outcomes, which suggests that stimuli for engaging in DIY are different for males as compared to females. Whereas men appear to be driven by a sense of craftsmanship when engaging in DIY, women seem to be motivated by feelings of empowerment associated with their DIY accomplishments. This difference is meaningful especially in the light of the shift of gender participation in DIY. With recent research indicating that women control $73 \%$ of household spending (an amount over $\$ 4.3$ trillion in the United States alone) 
(Silverstein \& Sayre, 2009), the implications for marketing are too important to ignore.

Historically, home improvement and maintenance have been viewed as a male domain, with social norms discouraging female participation (Gelber, 1997). However, the increasing democratization of the household in the early twentieth century recognized the right for women to use tools in the same way as men and supported female emancipation on the tool front (Gelber, 1997). The experience of World War II forced many women to reevaluate their roles in the home. New skills and the confidence gained from operating machines and using tools in the defense industry allowed women to take charge of home maintenance activities (Hartmann, 1983). While there was a steady expansion throughout the twentieth century of the kinds of do-it-yourself tasks women were willing to take on, postwar advertising literature still distinguished between male and female abilities and frequently assigned traditional stereotypical roles (Goldstein, 1998). For example, wives were typically portrayed as their husbands' helpmates rather than being recognized as having active roles in DIY activities (Gelber, 1997).

Although the conventional view of DIY as primarily a male domain is still very much alive (Foster, 2004), times are changing and the growing female interest in DIY activities is well documented (Shepard, 2010).

Women are steadily assuming more responsibility for home improvement, upkeep, and maintenance, with over $60 \%$ of women describing themselves as moderately or very handy, and nearly $90 \%$ reporting a high level of involvement in home improvement decisions (MedeliaMonitor, 2009). According to home improvement giant, Lowe's, women initiate $80 \%$ of all home improvement projects (2003), and statistics indicate women are currently outpacing men in DIY activities and DIY spending (Pushup Consulting, 2014). In conjunction with these changes DIY retailers are beginning to acknowledge the female DIY segment as one critical to their success and are initiating changes to better serve their female customers (Clifford 2011;

Rosenblum, 2013; Wood \& Lanchin, 2011). In fact, the recent failure of Home Depot's expansion into the

Chinese market has been blamed on the retailer's

failure to accommodate a female perspective when designing and merchandising their stores (Gao, 2013). Although much research has contributed to theories on gendered consumption, very little research is aimed toward the active participation of women in maledominant marketplaces. This article addresses this gap in the literature and extends Wolf and McQuitty's

(2011) findings by exploring the mechanisms that trigger women's empowerment through DIY. Because little research explores women's engagements in DIY, in-depth interviews are conducted with female DIYers

to address several research objectives. First, the $\mathrm{dy}^{-}$ namics that trigger feelings of empowerment in women who participate in DIY projects are explored. Second, to gain a more thorough understanding of gendered consumption, this article examines the mechanisms that explain a growing interest among women in a male-dominated field. Lastly, by choosing DIY as a research context, insight is added to an important, but largely overlooked consumer behavior phenomenon.

\section{CONCEPTUAL FOUNDATION}

In the broadest sense, empowerment is fundamentally about the acquisition of power. The construct is multifaceted, and researchers across multiple disciplines have emphasized various components of the construct. A clarifying concept in empowerment is that it is a process by which an individual who lacks power in a particular context sets a meaningful goal, takes action and gains knowledge, confidence, and self-efficacy from the action taken that generates a new found sense of power. According to Hollander and Offermann (1990) power may be experienced differently depending upon the context, the situational factors, and the personal qualities of an individual. Within the context of organizational life they identified three interrelated but distinct types of power. These include "power-over" (the power to control), "power-to" (the power to act), and "power-from" (the power to resist being controlled by others). Historically "power-over" has received the weight of attention in studies examining organizational issues and incorporating control-over elements including interpersonal relationships, information, resources, work procedures, rewards, and punishments (Ragins \& Sundstrom, 1989; Yoder \& Kahn, 1992).

"Power-over" is a relational construct rooted in social exchange theory where the relative power of the parties in an exchange depends upon the degree to which one party of the exchange is dependent upon the other (Pfeffer, 1981). To date, the marketing literature addressing consumer empowerment aligns with this perspective in that consumer empowerment is defined as giving consumers power throughincreased information or better understanding of processes involved in the creation of offerings (Harrison, Waite, \& Hunter, 2006; Rust \& Oliver, 1994). Internet resources continue

to fuel the power-over perspective of empowerment

by offering knowledge that enables consumers to negotiate service encounters and modify products in their favor (Davies \& Elliott, 2006; Geiger \& Prothero, 2007; Harrison, Waite, \& Hunter, 2006; Henry, 2005; Newholm, Laing, \& Hogg, 2008), by increasing consumer control through providing multiple choices (i.e.,

choice set composition, choice progress assessment, and choice information of other consumers) (Wathieu et al., 2002) or when acting in aggregate to influence companies to create products or services they would not otherwise produce (Fuchs, Prandelli, \& Schreier, 2010).

"Power-to," or psychological empowerment, differs from power-over empowerment because it is intrapersonal rather than relational in nature. "Power-to" emphasizes how people feel about themselves regard-

ing their ability to achieve a desired outcome in a specific domain (Zimmerman, 1995). The "power-to" 
conceptualization as associated with empowerment aligns closely with the notion of empowerment as a motivational force (Conger \& Kanungo, 1988), which is rooted in Deci's (1975) argument that motivational power is generated through an intrinsic human need for self-determination. Spreitzer (1995) built on the work of Conger and Kanungo (1988) and Thomas and Velthouse (1990) to expand upon early definitions of psychological empowerment to propose psychological empowerment should be viewed as a motivational construct consisting of four cognitions: (1) meaning, a feeling one's work has personal value; (2) competence, a belief personal effort will lead to successful performance; (3) self-determination, autonomy in choosing and initiating work activities; and (4) impact, the degree to which an individual's input influences the work outcome. Recent research confirms the validity of this model of psychological empowerment and substantiates its positive relationship to intrinsic motivation (Zhang \& Bartol, 2010).

The "power-from" conceptualization of empowerment is more similar to the "power-over" concept of empowerment in that it is a relational concept. In application, the "power-from" definition is generally used to address existing power imbalances among social classes or between genders. Shaw (2001) examined female empowerment in the context of leisure activities and determined it to be a central characteristic of resistance that enables women to create new opportunities and identities, which are not automatically assigned by traditional gender norms. Mosedale (2005) in her investigation of empowerment in development studies indicated empowerment provided an opportunity for women to redefine and extend what is possible for them in circumstances in which they were previously restricted to or compared to men. Resisting norms is a common theme in leisure and gender theory where women's feelings of empowerment is related to self-expression, self-confidence, and independence (Freysinger \& Flannery, 1992), perception of increased physical strength (Brace-Govan, 2004), the acquisition and mastery of new skills (Wheaton \& Tomlinson, 1998), and the pleasure of countering expectation about appropriate leisure activities (Auster, 2001).

Marketers have addressed empowerment primarily from a consumer perspective that emphasizes a singular "power-over" understanding of empowerment but have missed the opportunity to explore women's feelings of empowerment in everyday consumption and build upon the dimensions of empowerment that incorporate the "power-to" and the "power-from" forms of the empowerment concept. Popular culture as demonstrated in recent news articles, TV shows, and social media (e.g., DIY Network, www.bejane.com, Pinterest) suggest female empowerment penetrates everyday consumption activities at multiple levels. For example, the lifting of gender boundaries permitted female Harley Davidson riders to take control over their own bodies, own risks, and own expressions of sexuality (Martin, Schouten, \& Alexander, 2006).
The women in the Harley Davidson study enjoyed challenging gender expectations and the judgment of what they should or should not do.

Given that the social context for DIY activities has traditionally been regarded as a male domain, it provides an appropriate setting to examine female empowerment. In spite of the increase in legislation aimed at providing gender neutral policies in employment, education, and associated opportunities, there is strong evidence that traditional societal expectations generate cultural scripts that are difficult for women to overcome (Charles \& Bradley, 2002). Gender roles are initially shaped by parental expectations and reinforced by contemporary media such as Disney where girls are pretty princesses and boys are the heroes who save them (Carl, 2012). Recent studies indicate women continue to be discouraged from entering male-dominated careers because of societal factors such as insufficient role models, lack of career information, and sex-role stereotypes as well as by their personal self-concepts about gender appropriate choices (Gottfredson, 2006; Stromquist, 2013; Whitmarsh \& Wentworth, 2012).

Cues for gender appropriate activities are so deeply embedded in societal norms and symbols that household technologies themselves have become gendered through their association with male versus female users (Caterall \& Maclaran, 2002; Lieven, Grohmann, Hermann, Landwehr, \& Tilburg, 2014). While technologies associated with daily domestic chores (such as washing machines) are associated with women, the less routine household tasks associated with DIY activities (such as power drills) are most commonly used by men and are associated with maleness (Worth, Smith, \& Mackie, 1992). Consumer behavior theorists suggest that while existing studies on gender and consumption provide value, they have failed to contribute the development of substantive theory on the gender-consumer behavior relationship (Kacen \& Nelson, 2002). The current study tackles this issue head on by exploring the emotional dimensions and meaningfulness associated with experiential consumption by examining the thoughts and experiences of female DIYers. The study's findings underline the practical relevance of empowerment's role in the consumption process.

\section{METHOD}

Consistent with the research objective to explore women's feelings of empowerment through DIY practices, this study utilizes a qualitative methodology (Glaser \& Strauss, 1967; Strauss \& Corbin, 1998). The first phase of data collection began with informal interviews with female consumers intercepted at large home improvement stores located in the southern United States. These initial interviews served to enhance the authors' theoretical sensitivity and to develop the formal interview protocol. Once the interview questions were refined and finalized, the second phase of data collection began (Al-Mutawa, 
2013). In this phase, 19 formal in-depth interviews with self-professed female DIYers were conducted.

The recruitment of participants began with two personal contacts and thereafter a snowball sampling technique was utilized (Phillips \& Sego, 2011). This selection method was appropriate as women eagerly suggested other possible participants who have undertaken DIY projects. Informants ranged in ages from 28 to 54 and resided in the southern region of the United States. The study included participants engaging in various levels of DIY project difficulty. Informants with more experience normally reported taking on more challenging projects, whereas less-experienced participants reported less-challenging projects. More than half of the informants were neither married nor were they living with a significant other at the time of the interviews. Brief informant profiles with pseudonyms are presented in Table 1.

Depending on informant preference, the interviews took place at a university campus, a local coffee house, or at informants' homes. The formal interviews lasted approximately 60 minutes and were audio-recorded and immediately transcribed by one of the authors producing over 300 double-spaced pages of text. Informants were asked to share stories about their DIY projects, including those projects that were undertaken alone or with help from either friends or partners. Informants were probed during the interview process to elaborate on topics such as decisions they made along the lines of project initiation, execution, and finishing stages with almost all participants sharing multiple stories regarding their DIY behavior. In addition, informants shared stories about projects deemed to result in positive or less-than-positive experiences. They also reported on associated levels of project enjoyment, the involvement of their partners in the projects, and the respective tasks associated with shared projects.

The transcribed interview texts served as data for grounded theory analysis of female DIY consumption (Strauss \& Corbin, 1998). Themes, categories, and relationships emerged throughout the interview process, and the authors continued collecting interviews until the themes were saturated, and no additional refinements emerged from the addition of more participants (Glaser \& Strauss, 1967). Upon collecting the data, the authors assessed the experiential relevance of these themes to the informants in comparison with the literature. The literature associated with consumer behavior, consumer psychology, sociology, leisure, and gender was reviewed throughout the data collection phase. The process of alternating between reviewing relevant literatures and collecting data is a part of the immersion process indicative of grounded theory design (Strauss \& Corbin, 1998). Data analysis began using open coding, where the authors independently created abstract representations of important "events, happenings, objects, and actions and interactions" (Strauss \& Corbin, 1998, p. 102). The next step in the open-coding process involves grouping concepts into categories (Strauss \& Corbin, 1998). During this phase, theory began to emerge with the identification of variations of empowerment that formed dominant themes in the data. Discrepancies in the coding were discussed and resolved by the bigendered research team. In addition, member checks (Lincoln \& Guba, 1985 ) with the first five informants were performed to allow informants to reflect and assess the accuracy of the researcher's interpretations.

\section{FINDINGS}

The initial focus of the data analysis was to gain insight into women's DIY practices and explain the motivation of women to engage in an activity that is commonly perceived to be a male domain. The data supported the underlying role of empowerment in female DIY activities and provided a critical view of the concept of empowerment in female DIY consumption. The inquiry began by asking women to recall the most memorable or most recent DIY project and elaborate on the circumstances that triggered the project. Informants communicated their DIY behavior is negotiated and influenced by interactions of specific life events, personal situations, and societal expectations, which lead to various feelings of empowerment. The current analysis revealed five themes that generated feelings of empowerment.

\section{Empowerment through Project Initiation}

The data suggest initiating a DIY project can enhance a woman's feeling of empowerment. This was particularly true for married women or those in relationships. The women frequently spoke of situations in which they started DIY projects without notifying their spouses. Informants indicated an initiated DIY project in one's home equates to caring about the place, taking charge, and keeping order. A number of the informants suggested ownership comes with responsibility, and starting a project with a spouse reinforces a sense of shared responsibility. While some informants include their spouses in the process, for others it was important to complete the task independently-the following quote by Jennifer, a 40-year-old salesperson, explicates this idea.

My husband is not much into working on or around the house. He would help if I ask, but it's a bit like pulling teeth. Whether it's the yard, small remodeling jobs, or working on my Jet-ski, I want to try it myself. I'm not tearing a motor apart, but I can take care of maintenance or oil changes. I don't mind getting messy, because it means that I'm involved. ... I'll call for Craig [husband] if I absolutely can't move on by myself. (Jennifer)

For others like Charmaine, a 44-year-old accountant, project initiation means she has control of the project even though her physical contribution may be limited. Starting a project puts her in charge of making 
Table 1. Participant Profiles.

\begin{tabular}{|c|c|c|c|c|c|c|c|c|}
\hline & Participant & Age & Occupation & $\begin{array}{l}\text { Project } \\
\text { Type }\end{array}$ & $\begin{array}{c}\text { Years of } \\
\text { DIY Experience }\end{array}$ & $\begin{array}{c}\text { Marital } \\
\text { Status S/M }\end{array}$ & $\begin{array}{c}\text { Project Executed } \\
\text { Alone }\end{array}$ & $\begin{array}{l}\text { Duration of } \\
\text { Last Project }\end{array}$ \\
\hline 1 & Carolyn & 47 & $\begin{array}{l}\text { Wildlife } \\
\text { service }\end{array}$ & Home remodeling & 4 & M & & 2 years \\
\hline $\begin{array}{l}2 \\
2\end{array}$ & Debra $^{a}$ & 48 & $\begin{array}{l}\text { Marine } \\
\text { construction }\end{array}$ & Spring cleaning & 2 & M & & \\
\hline 3 & Jane & 53 & IT technician & $\begin{array}{l}\text { House exterior, } \\
\text { chairs }\end{array}$ & 10 & $\mathrm{~S}$ & $\mathrm{x}$ & 2 weeks \\
\hline 4 & Jennifer & 40 & Sales rep. & Landscaping & 5 & M & $\mathrm{x}$ & 3 months \\
\hline 5 & Mari & 53 & Casino service & $\begin{array}{l}\text { Furniture repair, } \\
\text { painting }\end{array}$ & 15 & $\mathrm{~S}$ & $\mathrm{x}$ & \\
\hline 6 & Lynn & 42 & Hair stylist & $\begin{array}{l}\text { Remodel home } \\
\text { business (flooring, } \\
\text { piping, windows) }\end{array}$ & 10 & M & & 2 years \\
\hline 7 & Louise & 54 & Professor & Remodeling kitchen & 30 & M & $\mathrm{x}$ & \\
\hline 8 & Trudy & 52 & $\begin{array}{l}\text { Business } \\
\text { developer }\end{array}$ & $\begin{array}{l}\text { Remodel bath, demo, } \\
\text { flooring, walls, } \\
\text { tiling }\end{array}$ & 22 & $\mathrm{~S}$ & $\mathrm{x}$ & 3 months \\
\hline 9 & Linda & 48 & $\begin{array}{l}\text { Office } \\
\text { manager }\end{array}$ & $\begin{array}{l}\text { Kitchen remodeling } \\
\text { (sink, ceiling, } \\
\text { appliances) }\end{array}$ & 5 & $\mathrm{~S}$ & & 1 month \\
\hline 10 & Patsy & 45 & $\begin{array}{l}\text { Marketing } \\
\text { manager }\end{array}$ & $\begin{array}{l}\text { Remodel bath (tiling, } \\
\text { floor, fixtures) }\end{array}$ & 7 & M & & 1 month \\
\hline 11 & Beth $^{a}$ & 43 & $\begin{array}{l}\text { Company } \\
\text { administra- } \\
\text { tion }\end{array}$ & $\begin{array}{l}\text { Light fixtures, } \\
\text { appliance repair }\end{array}$ & 10 & $\mathrm{~S}$ & $\mathrm{x}$ & 1 week \\
\hline 12 & Lori $^{\mathrm{a}}$ & 42 & $\begin{array}{l}\text { School admin- } \\
\text { istration }\end{array}$ & $\begin{array}{l}\text { Remodel home, } \\
\text { furniture repair, } \\
\text { landscaping }\end{array}$ & 6 & $\mathrm{~S}$ & & 1 month \\
\hline 13 & Belinda & 38 & Hair stylist & $\begin{array}{l}\text { Remodel home, } \\
\text { contracting }\end{array}$ & 8 & $\mathrm{~S}$ & $\mathrm{x}$ & 1 year \\
\hline 14 & Charmaine & 44 & Accountant & $\begin{array}{l}\text { Remodel kitchen, } \\
\text { landscaping }\end{array}$ & 12 & $\mathrm{~S}$ & $\mathrm{x}$ & 2 weeks \\
\hline 15 & Pam & 36 & Professor & $\begin{array}{l}\text { Remodel home, } \\
\text { repairs }\end{array}$ & $<1$ & $\mathrm{~S}$ & $\mathrm{x}$ & 10 weeks \\
\hline 16 & Elizabeth & 40 & $\begin{array}{l}\text { Project } \\
\text { manager }\end{array}$ & $\begin{array}{l}\text { Fight fixtures, } \\
\text { appliance repair }\end{array}$ & 10 & M & $\mathrm{x}$ & 2 weeks \\
\hline 17 & Lisa & 48 & Professor & Storage shelving & 14 & M & $\mathrm{x}$ & 2 months \\
\hline 18 & Jo & 31 & Student & Headboard building & 2 & $\mathrm{~S}$ & $\mathrm{x}$ & 1 week \\
\hline 19 & Mallory & 28 & Student & $\begin{array}{l}\text { Furniture } \\
\quad \text { refurbishing }\end{array}$ & 1 & $\mathrm{~S}$ & $\mathrm{x}$ & 3 weeks \\
\hline
\end{tabular}

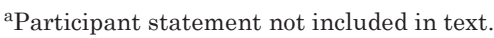

decisions about design, looks, finishes, and colors. Her notion of initiating a project communicates power over most aspects of the DIY project, like a manager.

Of course, most projects are joint projects. Sometimes they are just too complex to tackle by yourself. But I feel if I start the project I have more say about what it should look like. I'm in charge of the details ... like a project manager. (Charmaine)

Most of Charmaine's DIY experiences took place after her divorce, and her new life situation required her to perform projects on her own. The initiation and completion of the projects triggered feelings of empow erment to take on additional challenges her new sole home ownership presented. Belinda shared similar experiences, but her decision to initiate the project occurred under different circumstances. Her cottage near the water was nearly destroyed during a hurricane. She was faced with deciding whether to move in with her family or rebuild the home she lost.

I wasn't sure what to do. My family thought I was crazy to even think about rebuilding from what was left standing. They just wanted me to move home [to their home]. ... . You know, it's about commitment. I didn't do anything at first besides cleaning it as good as I could . . . My house was empty for about a year and a half, but when I got started on it, it was about a six month project. (Belinda)

Belinda explained her idea of taking charge was not giving up on her dream of a residence by the water. But more importantly, after disaster struck, rebuilding her property served the purpose of communicating her commitment to home ownership, the process 
of rebuilding, and the capabilities to take matters into her own hands, to her family. By initiating the rebuilding process, Belinda set the stage for her family and friends to respect her decision.

\section{Empowerment through Production Mastery}

Some informants expressed feelings of empowerment through learning new skills and developing expertise in new areas. Several women shared their DIY triumphs when reflecting on completed DIY projects. Women who communicated empowering feelings found these feelings emerging as they mastered a project on their own. This often included mastering unfamiliar challenges, tasks, and procedures requiring new learning. The emphasis on gaining and sharing knowledge was common and often tied to feelings of independence and confidence. Many informants felt this gave them the ability to gather relevant information, shop for the required materials, and complete the task without help from others. The following quote by Elizabeth, a 40-year-old project manager, highlights how repairing a clothes dryer on her own strongly impacted her sense of mastery and reduced her intimidation of seemingly complex machines.

I always had the mindset that things that are in a black box are complicated. But once you crack it open they are fairly easy. So maybe you should not be so freaked out about it. I'm not sure if I'm ready to take the washer apart but it definitely made me lose a little of my intimidation of enclosed machines. (Elizabeth)

Several informants expressed a newly discovered sense of competence after learning how to tackle DIY projects through TV shows, magazines, or the Internet. For these informants successful project completion increased their self-esteem and feelings of worthiness. For example, Pam, a 36-year-old academician shared:

You feel good about yourself when you learn and figure something out you never thought you would do. When I bought a house, I had to pull up the carpet before installing laminate floors. It took me awhile to learn how to do it and what tools to use, but after reading things online; I went down to Lowe's and asked them to show me where the tools were. I bought knee pads and tools and went to work . . It took me three days to pull out the carpet, but I felt mighty good about myself that I did it! (Pam)

Jane, a 53-year-old IT technician, who enjoys the outdoors, built a sail boat from a kit she ordered online. Later she felt a sense of pride answering questions from other sailors about the boat she had built. Linda, a 48year-old office manager, shared that her newly learned skills and abilities confirmed her self-sufficiency and put her in the position to be called upon by friends for her DIY expertise. She exemplifies a female DIYer who has been empowered through repeated exposure to DIY projects and has become proficient in her skills. She has learned how to use most tools but is still intimidated at the idea of using a nail gun. She is excited about new DIY challenges and prefers shopping in DIY stores when planning new projects. These women clearly share a sense of accomplishment, self-esteem, and confidence as a result of their DIY experience.

However, not all female DIYers enjoy the mainstream character of DIY and the perception DIY projects are as easy and quickly done as depicted in popular TV shows. For example, Louise, a 54-year-old academician, illustrates her pride in mastering projects led her to distinguish between "serious" and "pretend DIYers."

Some people watch TV shows and then they come over and tell me all the things they want to do. Those people make me crazy. You end up doing most of the work if asked to help. They want to put on their goggles, apron, and a tool belt . . . To me they just want to look right but not do it right. People that want to look like the people on TV are the ones I cannot work with. (Louise)

Louise's case exemplifies there is a difference between wanting to do DIY projects and the true mastering of tasks. Her remarks reveal active engagement and the associated learning facilitated her personal authority, independence, and self-satisfaction.

\section{Empowerment through Adding Economic Value to Goods and Services}

Most informants shared adding economic value to homes through DIY efforts afforded them empowering feelings. This was often due to the perception their own DIY efforts could produce greater economic outcomes than the work of professionals. Informants stated they received an ego boost when doing a project at less expense and of higher quality than if it were done by professionals. An important aspect of adding economic value through DIY efforts was informants would primarily rely upon their own labor, thus minimizing labor costs associated with professional services. The quotes below by Trudy, a 52-year-old business developer, and Jo, a 30-year-old student, highlight how feelings of empowerment are derived from adding economic value:

I always liked home improvement. I liked improving things. It's like you start off here [low] and end up here [high]. You get to make things that otherwise would cost a fortune. All these things increase the value of my home, and in a way [improve] my quality of life and standard of living. And you get to have fun, with some frustrating moments, while you do it. (Trudy)

I was able to use old plywood to build a head board that would have cost me a lot otherwise. I added a 
mattress topper and fabric I found on sale at Hobby Lobby. I enjoyed the project because I could make it for one third of what others buy it for in stores. (Jo)

Charmaine stated she is able to increase the economic value of her house by repainting. Also interesting was her perception of adding value by taking over parts of the professional's work in order to minimize cost. As a result, Charmaine (quote below) feels less dependent on professionals and more in charge of her own space.

I began with paint jobs, because paint has the ability to change a lot with relatively little cost and effort. I didn't know how to install counter tops or the sink. Although, I took it [the sink] out myself and only had them [professionals] put in a sink. They charge you for taking it out and in, so I saved some money by taking it out myself. It is little stuff like that that helped to get more done on the house. And as time goes on I don't have to ask anybody and can save on cost. (Charmaine)

\section{Empowerment through Unleashing Creative Potential}

Several informants articulated the idea that engaging in DIY activity allowed them to express their creative potential. Mari, a 53-year-old woman working in the casino industry, expressed her artistic creativity by her use of wall texture and paint.

My biggest home improvement thing is paint. Every room in here I painted in a unique way. This [particular room] is called faux painting, it is called Bellagio faux. I love trying out new textures that I find in stores in my house and on my walls then combining them with different colors. You can use all kind of materials to make a wall look unique. Sometimes I try to recreate styles from different time periods. It's almost like art in my home. (Mari)

Mallory, a 27-year-old student, enjoyed using her artistic skills to restore old furniture. She points out that adding unique colors and accessories combined with creative elements can give a scrap piece of furniture a new role in the home.

... picking out the colors of paint and finding antique knobs for the handles was my favorite part. I thoroughly enjoy DIY projects and I love unique pieces of furniture. The best part was that I turned something that looked 'hopeless' into a useful piece of furniture that also looks good. (Mallory)

For some, creativity went beyond choosing colors and working on design elements. Creative involvement can become complex, as in finding creative solutions for problems presented by DIY projects. The following quotes illustrate this idea.
I like the thought process. I like to think about how I can build it this way and I can support it that way and another way may also work. I just try it and see. I can figure out why it did not work. I like to solve problems. Just like my job, but hands on. I feel like a problem solver. (Louise)

I'm more involved in the planning and designing side of the DIY project. I have a very big stake in the design and how it is going to look afterwards and my husband is very involved in the execution. Though, it does not mean I only stick to designing. I did put a lot of the tile in by myself. I tiled and grouted. The task itself was fun because I could play around with various shapes of tiles; create a design from left-over pieces in places like the entrance ways and shower. (Carolyn)

There was, however, some distinction in involvement with the design elements and involvement with the physical labor of the task. For some women, the division of tasks reflected traditional gender roles shared by men and women in a collective household. Because the physical contributions to a DIY project seemed to be valued higher by some of their male spouses, informants voiced that by focusing on the creative elements and finding task solutions, they were able to maintain control over the project. However, as quoted above, Carolyn, a 47-year-old government wildlife scientist, is quick to state her physical contribution in the tile project to show equality in distribution of effort.

\section{Empowerment through Ownership}

Informants also felt empowered by gaining a sense of ownership when engaging in DIY projects. Ownership often results from reconstructing a purchased property and adding one's individual design and construction elements. In addition, the experience of transforming a newly purchased home to fit the new owner's identity built confidence through finishing DIY projects. The quote below by Lynn, a 42-year-old hair stylist, exemplifies how the sense of ownership is derived.

We had the choice of choosing a property that didn't really require any work. But I could not have done it [accept someone else's home as is]. I have to rip it apart and make it my own. How can it become yours if someone else had put it together? (Lynn)

Others stated taking part in the construction of projects results in familiarity of processes. The knowledge gained about one's surroundings can offer a sense of ownership and control. Louise shared that working on her own home added confidence and peace of mind.

I felt much more comfortable after that [modifications]. Sitting in the house I was often a little worried. What if there is a fire in the house, what are you going to do? Now I'm sitting in my house knowing 
I have a GMCI [Ground Fault Circuit Interrupters] on every single circuit. Electrical fires are not going to happen. At least not from my wiring! (Louise)

Charmaine also communicated that her extensive DIY experience enables her to tackle various challenges. By looking back at her DIY experience, she realizes that the things she was capable of doing made her feel strong and confident within her own space. She even takes it one step further and voices her resentment for peoples' perception that it takes a man to fix up a home.

Oh my god, it makes me feel strong. And I don't mean this in a feminist way, but rather by looking back at the things I have done on my homes. I've done it. Over the years I had people giving me a hard time about it 'You need to get married, you need a man.' And every time I would do a project I would step back and say - I don't need a man, I can do this on my own. (Charmaine)

Finally, Lisa, a 48-year-old academician, describes ownership as being in charge of timing. She explained her DIY projects are started and finished on her terms.

One thing that I like in particular is that I'm in charge of when to start and finish my project... This is different from my job, which often dictates appointments and time allocation. Being my own boss on [my] projects makes the work relaxing and fun. I get to decide what and when to learn through my projects. (Lisa)

Lisa's busy academic schedule determined "time" to be a cherished variable. Her work schedule is often controlled by others, thus taking ownership of her DIY projects begins with taking charge of the schedule. The decision of when and how much to work on her DIY projects translates to a sense of ownership over the process.

\section{DISCUSSION}

This research offers new insight into gendered consumer behavior by exploring women's feelings of empowerment in DIY consumption. Consumer research investigating the female perception of empowerment is restricted in area and application. Although a limited number of studies exist that address empowerment in areas of female consumption such as pregnancy (Geiger \& Prothero, 2007), lingerie (Granot, Greene, \& Brashear, 2010), and cosmetics (Coulter, Feick, \& Price, 2002), few have looked outside the narrow perspective of stereotypical female consumption (Martin, Schouten, $\&$ McAlexander, 2006). We address this gap in the literature by explicating the role of women's feelings of empowerment in every day consumption and by choosing DIY as a context this research extends Wolf and
McQuitty's (2011) model of DIY motivations and outcomes.

DIY consumption continues to be predominantly perceived as a male domain neglecting the reality that women play a prominent role in DIY activities. The current study examines women's participation in DIY using in-depth, structured interviews. Women who engage in DIY acquire a new found sense of control through increased information and understanding, an expanding sense of independence through breaking traditional gender barriers, and an elevated sense of selfworth through the experience of successful project completion. In sum, these women communicated feelings of empowerment that encompassed each of the three interrelated variations of the empowerment construct. While the concept of "power-over" historically received the majority of attention in consumer behavior, other forms of consumer empowerment, "power-from" and "power-to," have not to date been integrated into the exploration and understanding of everyday consumption activity. A meaningful contribution of the present research is its extension of a more fully nuanced understanding of the empowerment concept as it relates to the discipline of consumer behavior research. The following sections will explicate the forms of empowerment in the context of DIY consumption.

Power-over in essence is rooted in the exchange between parties. The power-over perspective is often linked to consumer control through an increased availability of information. Information (i.e., Internet, television, home improvement publications) empowers consumers by providing knowledge, which enables them to make more informed decisions. As knowledge shifts power to consumers it gives them the upper hand in negotiating between brands, in demanding price matching, and in exercising influence over product development.

The perspective of power-over empowerment was expressed by Trudy and Jo. Both women emphasized how their personal labor contributions in DIY projects gave them the power to control the processes and costs associated with repair and home design projects. There was consensus among the women in this study that their knowledge of design trends, branded goods, and material and project costs enabled them to not only make more informed decisions but also to take ownership of the projects they undertook. Women commonly became familiar with desired styles, designs, and material options long before project initiation. Their accumulation of knowledge led to the initiation of projects within the home, either conceptually and or physically, and enabled the women to take on responsibilities similar to a project manager. In this role women granted themselves oversight of the project and a higher level of control over the project outcome. In other words, the physical labor input contributed to the project was no longer the determining factor of who was in charge of decision making.

Another variation on the concept of empowerment is offered by the power-to or psychological power 
perspective. Power-to differs from power-over as it involves intrinsic elements and does not require a power disparity between two parties. The findings in the current study support the earlier findings of Wolf and McQuitty (2013) in that DIY activities were seen to inspire the development of personal values that exceed the practical value of a project. Power-to highlights the feelings individuals have regarding their abilities to secure a desired outcome in a given domain. This fact appears relevant for the process of DIY consumption as it directly affects how consumers feel about themselves and their work.

The power-to perspective is exemplified by a number of participants. Pam, for example, clearly points out the psychological rewards received by simply learning and figuring out new things. She finds intrinsic value in the work she completed and the new things she learned have personal significance. Elizabeth offers insight that illustrates the power-to perspective when she describes how her mastery of a seemingly complex machine provides intrinsic benefits by promoting positive self-perceptions of competence, ability, and autonomy. Successfully challenging the perception that enclosed machines, such as a clothes dryer, can only be repaired by a professional promotes her belief that personal effort will lead to successful performance. Both Pam and Elizabeth acknowledge the intrinsic reward inherent in "power-to" empowerment, which in turn fosters and strengthens the motivational force to pursue additional DIY in the future. The power-to concept may be critical to marketers because it opens up new venues and opportunities for developing marketing strategies that build upon powerful influences on consumer behavior. The linkage of power-to with intrinsic motivation creates strong, positive feelings regarding self-efficacy and fulfills the higher order need, which Abraham Maslow identified as "self-actualization" (Maslow, 1943, 1954, 1962).

A third variation of empowerment with meaningful implications for DIY marketing addresses the imbalances between genders and is known as power-from. The concept of power-from empowerment is revealed through the women's expressions of personal freedom relating to a diminishing dependence on spousal assistance and gender stereotypes. Research organized around leisure and gender has found leisure can provide a source of empowered, self-determined identities with which women can resist and undermine construction of traditional and normative femininity (Currie, 2004; Green, 1998; Wheaton \& Tomlinson, 1998). The authors observe a similar effect for women who engage in DIY. Women like Jennifer and Belinda are assertive when it comes to initiating action regarding household projects.

The women in this study communicated empowerment is not automatically derived by beginning a DIY project but rather is secured through interacting with others, overcoming adversity, and surpassing societal expectations. Their stories conveyed a view of empowerment as an iterative process facilitated through meeting challenges and acquiring new knowledge. Traditionally, the home signaled culturally accepted norms about appropriate household functions associated with male and female roles in everyday life, professional status, and power and ideology (Madigan and Munro, 1996). Such roles and their association with stereotypical notions of femininity and masculinity (Gallagher, 2006; Ling, 1998) are challenged by the participants. That DIY provides an avenue for female emancipation from traditional stereotypes is succinctly expressed by Charmaine, "I don't need a man, I can do this..."

Given the positioning of DIY as a male playing field, marketers should rethink the role of demographics in the approaches they employ when developing marketing strategies to serve the DIY segment. Considering the central role of empowerment and the rising trend of single female home ownership, marketers who target women DIYers may offer new opportunities to those who seek self-empowering projects. They can enhance participation, reengagement, and future revenue streams by developing comprehensive marketing strategies designed around themes associated with female self-fulfillment and independence from traditional gender barriers. The findings increase in relevance as women who initiate DIY projects are not hesitant to take on additional responsibilities outside their conventionally viewed gender roles to remain in charge.

Feelings of empowerment may also prompt future behavioral intentions such as word of mouth, repatronage of DIY retailers, increased levels of complexity on DIY projects, and encouragement of other women. Participants like Linda and Louise were viewed by other women as role models for DIY projects. Marketers may implement strategies involving opinion leadership. In addition, researchers could examine women's DIY behavior in the light of symbolic consumption (Otnes \& McGrath, 2001; Schouten, 1991). Women tend to better understand symbolic meaning in certain products and brands (Otnes \& McGrath, 2001), and symbolic consumption may be a path in which women communicate they possess competence in areas where it is generally not expected. With the increasing role of women as primary or independent consumption decision makers, the authors posit the area of female DIY behavior is especially relevant and the consumption of related goods can be meaningfully influenced by marketing strategies developed to build upon a comprehensive understanding of female empowerment within each of its various forms.

\section{REFERENCES}

Al-Mutawa, F. S. (2013). Consumer-generated representations: Muslim women recreating western luxury fashion brand meaning through consumption. Psychology \& Marketing, 30, 236-246.

Auster, C. J. (2001). Transcending potential antecedent leisure constraints: The case of women motorcycle operators. Journal of Leisure Research, 33, 272-298. 
Brace-Govan, J. (2004). Weighty matters: Control of women's access to physical strength. Sociological Review, 52, 503532.

Bush, A., Menon, A., \& Smart, D. (1987). Media habits of the do-it-yourselfers. Journal of Advertising Research, 27, 1420.

Carl, J. (2012). Gender vs. Sex: What's the difference? Montessori Life, 24, 26-31.

Caterall, M., \& Maclaran, P. (2002). Gender perspectives in consumer behavior: An overview and future directions. Marketing Review, 2, 405-425.

Charles, M., \& Bradley, K. (2002). Equal but separate? A cross-national study of sex segregation in higher education. American Sociological Review, 67, 573-599.

Chen, S., \& Chandler, J. D. (2009). Design it, your selfexperiences (DIY): Social creativity. In M. C. Campbell, J. Inman, \& R. Pieters (Eds.), Advances in consumer research (Vol. 37). Duluth MN: Association for Consumer Research. Clifford, S. (2011). Revamping, Home Depot Woos Women. The New York Times. Retrieved January 2014, from http://www.nytimes.com/2011/01/29/business/29home. html?_r_2\&

Conger, J. A., \& Kanungo, R. N. (1988). The empowerment process: Integrating theory and practice. Academy of Management Review, 13, 471-482.

Coulter, R. A., Feick, L. F., \& Price, L. (2002). Changing faces: Cosmetics opinions leadership among women in the new Hungry. European Journal of Marketing, 36, 12871308.

Currie, J. (2004). Motherhood, stress and the exercise experience: Freedom or constraint? Leisure Studies, 23, 225-242.

Davies, A., \& Elliott, R. (2006). The evolution of the empowered consumer. European Journal of Marketing, 40, 1106-1121.

Deci, E. L. (1975). Intrinsic motivation. New York: Plenum.

Foster C. (2004). Gendered retailing: A study of customer perceptions of front line staff in the DIY sector. International Journal of Retail and Distribution Management, 32, 442447.

Freysinger, V., \& Flannery, D. (1992). Women's leisure: Affiliation, self-determination, empowerment and resistance? Society and Leisure, 15, 303-321.

Fuchs, C., Prandelli, E., \& Schreier, M. (2010). The psychological effects of empowerment strategies on consumers' product demand. Journal of Marketing, 74, 65-79.

Gallagher, W. (2006). House thinking: A room-by-room look at how we live. New York: Harper Collins.

Gao, M. H. (2013). Culture determines business models: Analyzing home depot's failure case in China for international retailers from a communication perspective. Thunderbird International Review, 55, 173-191.

Geiger, S., \& Prothero, A. (2007). Rhetoric versus reality: Exploring consumer empowerment in a maternity setting. Consumption, Markets, and Culture, 10, 375-400.

Gelber, S. M. (1997). Do-It-Yourself: Constructing, repairing and maintaining domestic masculinity. American Quarterly, 49, 66-112.

Glaser, B. G., \& Strauss, A. L. (1967). The discovery of grounded theory: Strategies for qualitative research. Hawthorne, NY: Aldine de Gruyter.

Goldstein, C. M.(1998). Do-it-yourself: Home improvement in 20th century America. New York, NY: Princeton Architectural Press.

Gottfredson, L. S. (2006). Circumscription and compromise. In J. H. Greenhaus (Ed.), Encyclopedia of career development (pp. 650-664). Thousand Oaks, CA: Sage.
Granot, E., Greene, H., \& Brashear, T. G. (2010). Female consumers: Decision-making in brand driven retail. Journal of Business Research, 63, 801-808.

Green, E. (1998). Women doing friendship: An analysis of women's leisure as a site of identity construction, empowerment and resistance. Leisure Studies, 17, 171-185.

Harrison, T., Waite, K., \& Hunter, G. (2006). The internet, information and empowerment. European Journal of Marketing, 40, 972-993.

Hartmann, S. M. (1983). The home front and beyond: American women in the 1940s. Boston, MA: Twayne Publishers. Henry, P. (2005). Social Class, market situation, and consumers' metaphors of (dis)empowerment. Journal of Consumer Research, 31, 766-778.

Hollander, E. P., \& Offermann, L. R. (1990). Power and leadership in organizations. American Psychologist, 45, 179-189. Home Improvement Research Institute. (2014). September HIRI/IHS global insight forecast for $5.4 \%$ growth in 2013. Retrieved January 2014, from http://www. hiri.org/?page_CopyofMedia

Hornik, J., \& Feldman, L. P. (1982). Retailing implications of the do-it-yourself consumer movement. Journal of Retailing, 58, 44-63.

Kacen, J. J., \& Nelson, M. R.. (2002). We've come a long way, baby-Or have we? In P. Maclaran, E. Tissier-Desbordes, \& P. Maclaren (Eds.), Proceedings of the Sixth Conference on gender, marketing, and consumer behavior (pp. 291-308) . Paris: ESCP-EAP Printing Services.

Lieven, T., Grohmann, B., Hermann, A., Landwehr, J. R., \& Tilburg, M. (2014). The effect of brand gender on brand equity. Psychology \& Marketing, 31, 371-385.

Lincoln, Y. S., \& Guba, E. G. (1985). Naturalistic inquiry. Newbury Park, CA: Sage Publications.

Ling, R. D. (1998). Gender, class and home ownership: Placing the connections. Housing Studies, 13, 471-486.

Lowe's. (2003). Women aren't afraid to get their hands dirty; survey shows single, married women debunking home improvement's male image. Retrieved November 13, 2011, from http://media.lowes.com/article_print. cfm?article_id_1643

Madigan, R., \& Munro, M. (1996). House beautiful: Style and consumption in the home. Sociology, 30, 41-57.

Martin, D. M., Schouten, J. W., \& McAlexander, J. M. (2006). Claiming the throttle: Multiple femininities in a hypermasculine subculture. Consumption, Markets and Culture, 9, 171-205.

Maslow, A. H. (1943). A Theory of human motivation. Psychological Review, 50, 370-96.

Maslow, A. H. (1954). Motivation and personality. New York: Harper and Row.

Maslow, A. H. (1962). Towards a psychology of being. Princeton: D. Van Nostrand Company.

MedeliaMonitor. (2009). The 'Do-It-Yourself' survey. Holly' wood, FL: Medelia Inc.

Mosedale, S. (2005). Assessing women's empowerment: Towards a conceptual framework. Journal of International Development, 17, 243-257.

Newholm, T., Laing, A., \& Hogg, G. (2008). Assumed empowerment: Consuming professional services in the knowledge economy. European Journal of Marketing, 40, 994-1012.

Otnes, C., \& McGrath, M. A. (2001). Perceptions and realities of male shopping behavior. Journal of Retailing, 77, 111137.

Pfeffer, J. (1981). Power in organization. Marshfield, MA: Pitman. 
Phillips B. J., \& Sego, T. (2011). The role of identity in disposal: Lessons from mothers' disposal of children's possessions. Marketing Theory, 11, 435-454.

Pushup Consulting. (2014). DIY Chic. Pushup Consulting Co. Retrieved January 2014, from http://www. pushupconsulting.com/insights/diy/

Ragins, B. R., \& Sundstrom, E. (1989). Gender and power in organizations: A longitudinal perspective. Psychological Bulletin. 105, 51-88.

Ridgway, N. M., \& Price, L. L. (1994). Exploration in product usage: A model of use innovativeness. Psychology \& Mar keting, 11, 69-84.

Rosenblum, P. (2013). Home Depot's resurrection: How one retailer made its own home improvements. Forbes. Retrieved January 2014, from http://www.brainjuicer.com/xtra/ esomar_insights_2011_-_the_emotional_shopper.pdf

Rust, R. T., \& Oliver, R. W. (1994). Video dial tone: The new world of services marketing. Journal of Service Marketing, $8,5-16$.

Schouten, J. W. (1991). Selves in transition: Symbolic consumption in personal rites of passage and identity reconstruction. Journal of Consumer Research, 17, 412-425.

Schwartzlander, A., \& Bowers, J. S. (1989). Relationships between consumer characteristics and do-it-yourself behaviour (do-it-yourself activity). Journal of Consumer Studies and Home Economics, 13, 39-51.

Shaw, S. M. (2001). Conceptualizing resistance: Women's leisure as political practice. Journal of Leisure Research, 33, 186-201.

Shepard, A. (2010). DIY: The women doing it for themselves. Times Online, January 7. Retrieved March 2013, http://www.thetimes.co.uk/tto/life/article1750743.ece

Silverstein, M., \& Sayre, K. (2009). The female economy. Harvard Business Review, 87, 46-53.

Spreitzer, Y. M. (1995). Psychological empowerment in the workplace: Dimensions, measurement, and validation. Academy of Management Journal, 38, 1442-1465.

Strauss, A., \& Corbin, J. (1998). Basics of qualitative research: Techniques and procedures for developing grounded theory. Thousand Oaks, CA: Sage.

Stromquist, N. P. (2013). Education policies for gender equity: Probing into state responses. Education Policy Analysis Archives, 21, 1-28.

Thomas, K. W., \& Velthouse, B. A. (1990). Cognitive elements of empowerment: An "interpretive" model of intrinsic task motivation. Academy of Management Review, 15, 666-681.
Wathieu, L., Brenner, L., Carmon, Z., Chattopahyay, A., Wettenbroch, K., Drolet, A., et al. (2002). Consumer control and empowerment: A primer. Marketing Letters, 13, 297-305.

Watson, M., \& Shove, E. (2008). Product, competence, project and practice. Journal of Consumer Culture, 8, 69-89.

Wheaton, B., \& Tomlinson, A. (1998). The changing gender order in sport? The case of windsurfing subcultures. Journal of Sport and Social Issues, 22, 252-274.

Whitmarsh, L., \& Wentworth, D. K. (2012). Gender similarity and gender differences of women's \& men's career patterns. Career Development Quarterly, 60, 47-64.

Williams, C. C. (2008). Re-thinking the motives of do-ityourself (DIY) consumers. International Review of Retail, Distribution and Consumer Research, 18, 311-323.

Wolf, M., \& McQuitty, S. (2011) Understanding the do- ityourself consumer: DIY motivations and outcomes. Academy of Marketing Science Review, 1, 154-170.

Wolf, M., \& McQuitty, S. (2013). Circumventing traditional markets: An empirical study of marketplace motivations and outcomes of consumers' DIY behaviors. Journal of Marketing Theory and Practice, 21, 195-209.

Wood, O., \& Lanchin, W. (2011). The Emotional Shopper, Brainjuicer. Retrieved January 2014, from http://www.brainjuicer.com/xtra/esomar_insights_2011__the_emotional_shopper.pdf

Worth, L. T., Smith, J., \& Mackie, D. M. (1992). Gender schematicity and preference for gender-typed products. Psychology \& Marketing, 9, 17-30.

Yoder, J. D., \& Kahn, A. S. (1992). Toward a feminist understanding of women and power. Psychology of Women Quarterly, 16, 381-388.

Zhang, X., \& Bartol, K. M. (2010). Linking empowering leadership and employee creativity: The influence of psychological empowerment, intrinsic motivation, and creative process engagement. Academy of Management Journal, 53, 107128.

Zimmerman, M. A. (1995). Psychological empowerment: Issues and illustrations. American Journal of Community Psychology, 23, 581-599.

Correspondence regarding this article should be sent to: Marco Wolf, Associate Professor, Department of Marketing, University of Southern Mississippi, 730 East Beach Blvd, Long Beach, MS 39560 (marco.wolf@usm.edu). 